Kosztopulosz Andreász - Kuruczleki Éva (szerk.) (2020): Társadalmi és gazdasági folyamatok elemzésének kérdései a XXI. században. Szegedi Tudományegyetem Gazdaságtudományi Kar, Szeged, https://doi.org/10.14232/tgfek21sz.19

\title{
Pálinkafogyasztási szokások Magyarországon
}

\author{
Mucha László - Oravecz Titanilla - Totth Gedeon
}

A pálinka megitélése az elmúlt két évtizedben pozitiv irányban változott, a negativ sztereotípiák eltünöben vannak, sikere töretlen, a fogyasztók számára a pálinka egyre inkább tradíciót, értéket képviselö igazi magyar ital. Jelen tanulmány célja a pálinkához kapcsolódó fogyasztói attitüd komponensek azonositására irányuló empirikus kutatás szakirodalmi megalapozása. A többlépcsös kutatási folyamat elsö fázisa a hazai szakirodalom áttekintése, valamint egy 2018 as kvalitativ felmérés értékelése hagyományos tartalomelemzéssel. A pálinkával kapcsolatos attitüdökben az elmúlt 6-10 évben olyan változás történt, ami a pálinka-imázs javulásának lassulását jelentette. Mindenképpen érdemes továbbra is erösiteni a pálinka pozicionálását a minél szélesebb körü ismertség, és elismertség érdekében, hiszen a pálinka értékes alapanyagból elóállitott hazai szeszes ital, mely kategóriájában értékét tekintve felveszi a versenyt a világszerte elismert konkurens termékekkel.

Kulcsszavak: pálinkafogyasztás, helyi élelmiszer, Hungarikum, vásárlási attitüdök

\section{Bevezetés}

Jónás (2006) szerint hazánkban a pálinkakultúrának, mely magában foglalja a gyümölcspárlat készítésének és fogyasztásának a hagyományait, szertartásait, évszázados múltja van. A 19. század közepén az országban szinte minden nagyobb uradalom, gazdaság, illetve település rendelkezett saját szeszfőzdével. Totth (2009), Totth et al. (2018b) szerint a Pálinkatörvény életbelépése, és Magyarország uniós taggá válása, valamint az évezred első évtizedében történt törvényi szabályozások megteremtették a lehetőségét a pálinka magas minőségü, értékes magyar italként történő pozícionálásának. Panyik-Béli (2008), valamint Béli (2013) szerint az uniós csatlakozási tárgyalások során a szeszes italok szabályozásának harmonizációja kiemelt figyelmet kapott. A tárgyalások eredményeként született meg a szeszes italok meghatározásáról, megnevezéséről, kiszereléséről, címkézéséről és földrajzi árujelzőinek oltalmáról szóló, Európai Parlament és a Tanács által jegyzett, 110/2008/EK rendelet, amelynek értelmében uniós oltalomban részesül a „Pálinka” és „Törkölypálinka” megjelölés, vagyis a pálinka elnevezés kizárólag Magyarországon (illetve barackpárlatok esetében további 4 osztrák tartományban) használható. A 2008as EK rendelethez képest a 2008. évi LXXIII. törvény további elöírásokat tartalmaz a pálinka készítésével és névhasználatával kapcsolatban. Eszerint csak az az ital nevezhető pálinkának, amely 100 százalékban Magyarországon termelt nemes és vadgyümölcsböl, szőlőtörkölyből illetve aszútörkölyből készítettek, Magyarországon cefrézték, érlelték és palackozták. A pálinka minimum 37,5 fokos, és semmilyen adalékanyagot nem tartalmazhat. A jogszabály tartalmazza a pálinka és törkölypálinka készítésénél felhasználható segédanyagok listáját is. A törvény továbbá meghatározza azt is, hogy a pálinka illetve törkölypálinka bármilyen arányú keverésével készült 
terméket - még akkor is, ha a termék alkoholtartalma 100 százalékban e két összetevőből származik - csak szeszesitalnak lehet nevezni. A jogszabály értelmében a bérfőző által, vagy otthon előállított termékekre nem alkalmazható a pálinka megnevezés, csak a párlat. A pálinka iránti érdeklődés növekedése, a pálinkával kapcsolatos strukturális változások, valamint a közösségi marketingtevékenység pálinkára történő kiterjesztésének a lehetősége Totth et al. (2017) megfogalmazásában az eddigieknél is fontosabbá tették a fogyasztói szokások, preferenciák, illetve a pálinkával kapcsolatos attitüdök minél alaposabb ismeretét. Balázs (2012) valamint Harcsa et al. (2014) felhívják a figyelmet arra, hogy habár a pálinka minőség szempontjából mára mindenképpen a világ élvonalába került, ennek ellenére mégsem ismerik a legtöbb országban, illetve hazánkban sem mindenki úgy, ahogyan az ágazat szereplöi szeretnék. Panyik (2006) rámutat, hogy a fogyasztókat a technológiai hibáktól mentes, jó minőségü termékekkel kell megismertetni, hogy megfelelő kép alakuljon ki bennük a pálinkáról. Azonban ahogy arra Totth et al. (2016) felhívja a figyelmet, a törvényi szabályozás megváltozása, a házi főzés engedélyezése jelentős kárt okozott a kereskedelmi főzdéknek, akik úttörő szerepet játszottak a pálinka imázsának a javításában, és a pálinkának, mint magas minőségủ értékes magyar italnak az elfogadtatásában. A 2010 öszén megváltozott jövedéki adó szabályozás következtében ugyanis lehetővé vált magánszemélyek számára, hogy adómentesen maguk is fözzenek saját fogyasztásra évente legfeljebb 50 liter pálinkát. Az otthoni pálinkafózés engedélyezése jelentősen visszavetette a kiskereskedelmi forgalmat, a házi pálinkafözés miatt a minőségi termékek fogyasztása harmadával, termelésük pedig háromnegyedével zuhant le néhány év alatt. A kereskedelmi fözés visszaesése a bérfőzdék termelésének a növekedésével párosult. 2019. január elsejétől általánosan 20 százalékkal emelkedett a népegészségügyi termékadó (NETA) az egészségi kockázatot jelentő ételek és italok esetében, az adóköteles italok körébe tartoznak 2019-töl a gyümölcspárlat, a pálinka, és a gyógynövényes italok is. A bérfőzdékre nem vonatkozik a NETA, a literenként 1700 forintos bérfőzési díj fele a szeszadó. A magánfözésért literenként 700 forintot kell fizetni, amit párlatjegy igénylésével róhatnak le az érintettek. A magánfözésben elóállított párlat valódi nagyságára csak becslések vannak. Ezen változások nem a minőség növekedésének az irányába hatottak. A Pálinka Nemzeti Tanács szerint a helyzet az ágazat sikerességét veszélyezteti, valamint felhívják a figyelmet a magánfözés okozta feketekereskedelem problémájára is (https://www.palinkanemzetitanacs.hu/hu/aktualitasok/42). A fogyasztók ráadásul keverik a pálinkákat a pálinkajellegü italokkal, vagyis azokkal, amelyek a köztudatban helytelenül pálinkaként jelennek meg, de a Pálinkatörvény elóirásainak nem felelnek meg. Szegedyné et al. (2017) szerint az emberek többségének a pálinka napjainkban is a „házi pálinkát” jelenti (amely jövedéki szempontból valójában nem is pálinka, hanem párlat), amelyhez minőségi szempontból gyakran kedvezötlen tulajdonságokat társítanak. Főként emiatt szükséges a termék újra pozicionálása, amelyhez elengedhetetlen a fogyasztói igények, és ismeretek minél részletesebb elemzése. Fodor et al. 2011-ben készült tanulmányában hívja fel a figyelmet arra, hogy idővel a nemzeti imázst hordozó italunk lehetne a pálinka, éppen úgy, mint a franciáknak a konyak, az angoloknak, skótoknak a whisky, vagy a mexikóiaknak a tequila. Mint minden tudományos igénnyel készített tanulmány 
esetében, itt is felmerült annak a lehetősége, hogy a pálinkafogyasztást, legalább is a szakirodalmi áttekintés szintjén nemzetközi kontextusban vizsgáljuk. Ettől azonban jelen esetben eltekintettünk, mégpedig két okból. Egyrészről a pálinka a magyar történelemben egyfajta szakrális italnak tekinthető (Totth 2009), melynek a szerepe túlmutat az átlagos alkoholos italok szerepén, és melynek a fogyasztása, jórészt egészségügyi állapotokhoz (fogfájás, gyomorrontás stb.,), illetve un. határátlépési helyzetekhez (keresztelö, temetés, áldomás, disznóvágás stb.) kapcsolódott. Ezekben jelentősen eltér az általunk ismert égetett szeszesitalok fogyasztási kultúrájától, illetve ezeknek a kultúráknak a fejlődésétől. Másrészről úgy ítéltük meg, hogy a más, hasonló jellegü alkoholos termékek fogyasztásával kapcsolatos összehasonlítás mélyebb kutatást igényel, melyet szándékunkban áll az elkövetkezendőkben megejteni.

\section{Szakirodalmi áttekintés}

Szegedyné et al. (2017) szerint a KSH nem méri külön a pálinka fogyasztásának volumenét, így erről leginkább a jövedéki statisztikák adnak kézzelfogható kimutatást (1. táblázat).

1. táblázat A bérfőzetett és a kereskedelmi fözdékből szabad forgalomba bocsátott párlatok és pálinkák mennyisége 2010-2015 között

\begin{tabular}{|c|c|c|c|c|c|c|}
\hline & 2010 & 2011 & 2012 & 2013 & 2014 & 2015 \\
\hline Bérfözés, ezer hektoliterfok & 4525,99 & 6174,09 & 6874,77 & 7402,75 & - & - \\
\hline Kereskedelem, ezer hektoliterfok & 730,01 & 852,14 & 881,33 & 744,63 & 723,72 & 908,50 \\
\hline
\end{tabular}

Forrás: Nemzeti Adó- és Vámhivatal, 2004-től, in Szegedyné et al. 2017, 161. o.

Az Agrárgazdasági Kutató Intézet 2016-os jelentése szerint a pálinkakészítés többnyire szezonális tevékenység, 2016-ban átlagosan 138 üzemnapon történt a pálinkafőzés, napi 10 órán keresztül. A pálinkafőző és a desztillált szeszesital-gyártó szervezetek több mint 70 százaléka 60 százaléknál magasabb kapacitáskihasználtsággal dolgozott 2016-ban. 2017-ben átlagosan 135 üzemnapon történt a pálinkafőzés napi 10 órán keresztül. A 220 adatküldő pálinkafőző szervezet több mint háromnegyede 60 százaléknál magasabb kapacitáskihasználtsággal dolgozott 2017-ben. A nagyon alacsony, alacsony és közepes kapacitáskihasználtságú üzemek részaránya csökkent, ugyanakkor a magas és nagyon magas kapacitáskihasználtsággal rendelkező vállalkozások részaránya nőtt 2016-ról 2017-re (2. táblázat). Az AKI jelentése sajnos nem tér ki a válaszadó vállalkozások üzemméretére, vagy jellegére. 
2. táblázat Alkoholtartalmú italok gyártásának kapacitáskihasználtsága, 2016-2017

\begin{tabular}{lcccccc}
\hline & & \multicolumn{5}{c}{ Kapacitáskihasználtság, százalék } \\
\cline { 3 - 7 } $\begin{array}{l}\text { Gyártóvonal } \\
\text { megnevezés }\end{array}$ & Év & $\begin{array}{c}0-20 \% \\
\text { Nagyon } \\
\text { alacsony }\end{array}$ & $\begin{array}{c}20,01-40 \% \\
\text { Alacsony }\end{array}$ & $\begin{array}{c}40,01-60 \% \\
\text { Közepes }\end{array}$ & $\begin{array}{c}\text { 60,01-80\% } \\
\text { Magas }\end{array}$ & $\begin{array}{c}80,01-100 \% \\
\text { Nagyon magas }\end{array}$ \\
\hline \multirow{2}{*}{ Pálinkafözés } & 2016 & 3,1 & 10,0 & 15,1 & 21,2 & 50,6 \\
& 2017 & 1,8 & 7,7 & 11,4 & 26,8 & 52,3
\end{tabular}

Forrás: AKI Agrárstatisztikai Információs Osztály, Élelmiszeripari kapacitásjelentés, 2016. év (revízió 2018. 5. hó), I. évfolyam 1. szám, 2017, 41. o.; Élelmiszeripari kapacitásjelentés, 2017. év, II. évfolyam 2. szám, 2018, 47. o.

\subsection{Pálinkafogyasztásra irányuló hazai vizsgálatok}

A pálinka iránti érdeklődés növekedése, a pálinkával kapcsolatos strukturális változások, valamint a közösségi marketingtevékenység pálinkára történő kiterjesztésének a lehetősége az eddigieknél is fontosabbá tették a fogyasztói szokások, preferenciák, illetve a pálinkával kapcsolatos attitüdök minél alaposabb ismeretét. Ebben a fejezetben összefoglaljuk a pálinkára vonatkozó fogyasztói szokásokat vizsgáló kutatások eredményeit. A tanulmányokat időrendben mutatjuk be a 3. táblázatban.

3. táblázat Pálinkafogyasztásra irányuló hazai vizsgálatok, 2003-2019

\begin{tabular}{|c|c|c|c|c|}
\hline Év & Kutatás & Célcsoport & Kutatás módszere & Legfontosabb megállapítások \\
\hline 2003 & OszKö-TNS & Országos & Kérdőívezés & $\begin{array}{l}\text { Tradíciókhoz köthető fogyasztás } \\
\text { Tájékozatlanság }\end{array}$ \\
\hline $\begin{array}{l}2007 \\
2008 \\
2009\end{array}$ & $\mathrm{NRC} \mathrm{Kft}$ & Fiatalok & Kérdőívezés & $\begin{array}{l}\text { Javuló imázs } \\
\text { Bizalom fontossága } \\
\text { Házi „pálinka” kedvező imázsa }\end{array}$ \\
\hline 2008 & GFK & Országos & Kérdőívezés & $\begin{array}{l}\text { Növekvő érdeklődés } \\
\text { Nosztalgia, vidéki hangulat, magyarság } \\
\text { Gyenge informáltság }\end{array}$ \\
\hline 2011 & Totth et al. & Országos & Kérdőívezés & $\begin{array}{l}\text { Házi „pálinka” preferencia } \\
\text { A termékjellemzőket a vásárlás célja határozza meg } \\
\text { Határátlépési helyzetek }\end{array}$ \\
\hline 2011 & Fodor et al. & Országos & $\begin{array}{l}\text { Egyéni interjú, } \\
\text { fókuszcsoport }\end{array}$ & $\begin{array}{l}\text { Eseményekhez, társasághoz köthető fogyasztás } \\
\text { „Szakrális” jelleg } \\
\text { Határátlépési helyzetek } \\
\text { Házi „pálinka” preferencia }\end{array}$ \\
\hline 2016 & Totth et al. & $\begin{array}{l}\text { X és az Y } \\
\text { generációk }\end{array}$ & $\begin{array}{l}\text { Egyéni interjú, } \\
\text { fókuszcsoport }\end{array}$ & $\begin{array}{l}\text { Különleges, értékes magyar termék } \\
\text { Javuló imázs }\end{array}$ \\
\hline 2017 & Totth et al. & Fiatalok & $\begin{array}{l}\text { Egyéni interjú, } \\
\text { fókuszcsoport } \\
\text { Kérdőívezés }\end{array}$ & $\begin{array}{l}\text { Igazi magyar termék, Hungarikum } \\
\text { Családi, baráti összejövetelek itala }\end{array}$ \\
\hline 2017 & $\begin{array}{l}\text { Szegedyné } \\
\text { et al. }\end{array}$ & Országos & Kérdőívezés & $\begin{array}{l}\text { „Magyaros” ital } \\
\text { Különleges, ritka alkalmakhoz köthető fogyasztás } \\
\text { Tájékozatlanság } \\
\text { Határátlépési helyzetek } \\
\text { A termékjellemzőket a vásárlás célja határozza meg }\end{array}$ \\
\hline 2018 & Totth et al. & Fiatalok & $\begin{array}{l}\text { Egyéni interjú, } \\
\text { fókuszcsoport, } \\
\text { Kérdőívezés }\end{array}$ & $\begin{array}{l}\text { Házi „pálinka”töretlen nimbusza } \\
\text { A termékjellemzőket a vásárlás célja határozza meg }\end{array}$ \\
\hline
\end{tabular}

Forrás: saját szerkesztés 2019. 
2003-ban az Agrármarketing Centrum megbízásából készült OszKő-TNS tanulmány a pálinka marketingstratégiájának a kapcsán foglalkozott a fogyasztói szokásokkal. A vizsgálat megállapította, hogy a pálinka fogyasztása alapvetően tradíciókhoz köthető, ezek határozzák meg a fogyasztási alkalmakat. A kutatás kiemelte a tájékozatlanságot, mely mind a fogyasztókat, mind pedig a kereskedelmet jellemzi. Megfigyeléses vizsgálatai alapján üzlettípustól függő, jelentősen eltérő pálinka kínálatról számolt be.

Az NRC Kft. 2007, 2008, illetve 2009. évi, a fiatalokat célzó vizsgálatai a pálinka imázsának határozott javulását mutatták, mely a torokkaparós, erős, ütős, „,berugatós” terméktől, egy trendi, társasági eseményen, fesztiválon fogyasztható irányba változott. Ugyanakkor ez a vizsgálat is kiemelte a bizalom szerepét a vásárlás során, mely egyértelmúen a házi pálinka kedveltségét jelezte.

2008-ban szintén az Agrármarketing Centrum megrendelésére a GFK Hungária Piackutató Intézet készített felmérést 1000 fős reprezentatív mintán. Ennek alapján jelentősen növekvő érdeklődésröl, nagyszámú új vásárlóról számoltak be. Ugyanakkor kiemelték a fogyasztók gyenge informáltságát, a kereskedelmen kívüli beszerzések igen nagy arányát. Vizsgálatuk szerint a pálinka név megöregedett, de nem üresedett ki, így társíthatók hozzá új gondolatok. A fogyasztók pálinkával kapcsolatos attitüdjei leginkább: nosztalgia, vidéki hangulat, magyarság. Az AMC 2008-as pálinka kampányának (amelyet egy fogyasztói megkérdezés alapozott meg) a célja az volt, hogy megszabadítsa a pálinkát a rárakódott negatív jelzőktől, 2009ben pedig a minőségi, tiszta, hazai gyümölcsből készült ital jelleg hangsúlyozása volt a cél (Fodor et al. 2011).

Totth et al. 2011-es, kvalitatív és kvantitatív kutatásai megerősítették a házi pálinka preferenciáját, ugyanakkor rámutattak arra, hogy a különböző célokra történő vásárlásoknál a vásárlói preferenciák, és ezzel párhuzamosan a költési hajlandóság eltérő. Az említett szerzők igen jelentős számú kvantitatív és kvalitatív mintán végzett kutatásai azt mutatták, hogy a pálinka elöállításában, és kínálatában bekövetkezett fejlődéssel a fogyasztók nem igazán tudtak lépést tartani. Ez a disszonancia elsősorban a márkaismeret alacsony szintjében mutatkozott meg a legmarkánsabban (Totth et al. 2011a). Totth et al. szintén 2011-ben végzett, egy másik kutatásában a vásárlást meghatározó preferenciarendszert differenciáltan vizsgálták. Az interjúkból kiderült, hogy a preferenciarendszerben az íz, a csomagolás, az ár végeztek az élen, az alkoholtartalom és a márka - bár kevesebb említéssel - de a lényegesebb elemek közé kerültek. A vásárlás célja bizonyos mértékben differenciálta a legfontosabb szempontok sorrendjét, de a preferenciarendszert uraló elemek körét nem (Totth et al. 2011b). A preferenciarendszer vizsgálata kapcsán megállapították azt is, hogy a pálinka esetében szembetünő a márkaismeret hiánya, de a márkanév mellett a termelöi név vagy a tájegység sem voltak a vásárlási döntésben igazán nagy szerepet játszó elemek.

Fodor et al. 2011-ben végzett kutatásukban az interjúalanyok nyilatkozataiból arra következtettek, hogy a pálinka fogyasztása legjellemzőbben eseményekhez, társasághoz kötődik. Sokan említették, hogy rokonokkal együtt pálinkával koccintanak egy-egy jeles alkalomra. A pálinka fogyasztása összeforr a baráti társasággal, családi pillanatokkal, egyrészt azért, mert „elindítja a beszélgetést” másrészt pedig, mert „ünnepi hangulatot kölcsönöz az együttlétnek”, így „kiválóan 
alkalmas a jó hangulat megteremtésére, a feszültség oldására”. Vizsgálatukban az alanyok többsége a hagyományos ízeket (szilva, körte, barack) kedvelte. A kutatásban megkérdezett fogyasztók túlnyomó többsége egyetértett (teljesen vagy inkább egyetértett) abban, hogy a pálinka egy igazi erős ital (96\%), magyar termék (95\%) és hogy hungarikum (94\%). A válaszadók többsége tisztában volt azzal is, hogy a pálinka csak gyümölcsböl készül (57\% teljesen egyetértett, további $23 \%$ inkább egyetértett az állítással). A házi pálinkának a bolti pálinkákkal szembeni preferenciája abban is megmutatkozott, hogy a válaszadók hét tizede (70\%) egyetértett azzal, hogy a bolti pálinka nem olyan jó, mint a házi. Felmérésük is bizonyította, hogy hazánkban a pálinka fogyasztásának egyfajta „szakrális” jellege van, azaz a pálinkafogyasztás erősen kötődik az élet fontos eseményeihez, „határ-átlépési” helyzetekhez, mint az esküvő, keresztelő, áldomás, vagy temetés, stb.

2016-ban Totth et al. újabb kutatást végeztek, és megállapították, hogy megváltozott a pálinka imázsa, szinte kizárólag pozitív fogyasztói megítélés társult hozzá. Már nem az idős, falusi ember egyszerü italának tekintették a megkérdezettek, hanem különleges, értékes magyar termékként jellemezték. A szerzők szerint a pálinka az ,átpozícionálódás” szakaszában van, és a kommersz ital helyett egyre inkább olyan italként tekintenek a pálinkára, amely tradicionális jellege mellett számos egyéb érték hordozója. Kutatásukban vizsgálták az X és az Y generációk pálinkafogyasztási szokásait, a pálinkával kapcsolatos preferenciáit és attitüdjeit. Megállapították, hogy a két generáció pálinkához kapcsolódó viszonya sok hasonlóságot mutat, de ugyanakkor vannak eltérések.

2017-ben Totth et al. szintén fiatalokon végzett kutatásukban megállapították, hogy ez a generáció leginkább a whiskyt, a pálinkát és a vodkát preferálja nagyjából hasonló kedveltséggel. A legtöbb fiatal szeszesital vásárló családi baráti összejövetelekre vásárol alkoholt, ezeknél az alkalmaknál is a preferált választás a pálinka, whisky és a vodka. A válaszadók közel kétharmada, $65 \%$-a vett már pálinkát családi, baráti összejövetelekre, ünnepi alkalmakra pedig közel háromnegyedük vásárolt már ilyen szeszes italt. A pálinkával kapcsolatos állítások közül tízből kilenc válaszadó szerint a pálinka igazi magyar termék, hungarikum. A fiatal fogyasztók több, mint háromnegyede (79\%-a) szívesen próbál ki pálinkakülönlegességeket. A válaszadók többsége egyetértett azokkal az állításokkal, melyek szerint a bolti pálinka nem olyan jó, mint a házi, illetve, hogy a pálinka csak gyümölcsből készül. A fiatal pálinkafogyasztók legkevésbé azzal az állítással értettek egyet, miszerint a pálinkát inkább csak különleges alkalmakon fogyasztják, illetve, hogy kicsit régimódi. A szeszes ital vásárló fiatalok háromnegyede vásárolt már pálinkát otthoni fogyasztásra, családi ünnepségre, baráti összejövetelre vagy ajándékként. A fiatal fogyasztók szeszesital vásárláskor a pálinka mellett a whiskyt és a vodkát preferálják. A legtöbb szeszesital-vásárló családi baráti összejövetelekre vásárol alkoholt. Pálinkafajták közül elsősorban a szilvát, az epret, és a kajszibarackot választanák. A fiatalok körében személyiségjellemzőik alapján négy jól elkülöníthető szegmens mutatható ki, amelyek fogyasztási szokásaikat, attitüdjeiket tekintve eltéréseket mutatnak. A fogyasztói csoportok közötti eltérést az együttérzés, segítségnyújtás valamint a hagyományok tisztelete személyiségjegyek faktorai okozzák leginkább. A mintában négy jellegzetes fogyasztói csoportot azonosítottak, amelyek a pálinkával kapcsolatos 
attitüdjeik, a fogyasztás alkalma, és demográfiai jellemzőik alapján különíthetők el egymástól. A szerzők által használt megnevezések a fogyasztói csoportokra: „Független kreatívok”, „Tradicionális értékrendet követők”, „Együttérző boldogságkeresők”, „Biztonságkeresők”

Szintén 2017-ben végzett a pálinkafogyasztásról átfogó tanulmányt Szegedyné et al. (2017). Az általuk megkérdezettek a pálinkát szinte egyöntetüen „magyaros” italnak tartották, azonban sokan a technikai és technológiai szempontból kicsit vagy nagyon is hibás terméket is igazi pálinkaként azonosítják. Kutatásuk megerősítette a korábbi vizsgálatok eredményeit, miszerint a pálinka fogyasztása a többség számára különleges, ritka alkalmakhoz köthető. A szerzők klaszteranalízis segítségével négy fogyasztói csoportot különítettek el, melyeket: Érdeklődők, Passzív elfogadók, Pálinkakerülők és Mindenivók- nak neveztek el. A klaszterek között jellemzően a fogyasztási gyakoriság és a pálinkához füződő viszony mentén tapasztaltak eltérést. Eredményeik alapján a férfiak nagyobb gyakorisággal fogyasztanak pálinkát, mint a nők. Életkor tekintetében az 50 év felettiek és a 18-24 év közöttiek csoportjában volt található a legtöbb olyan válaszadó, aki kifejezetten gyakran fogyaszt pálinkát. Megállapították, hogy a válaszadóik ajándékba magasabb összegért vásárolnak pálinkát, mint saját fogyasztásra. 0,5 liter pálinka megvásárlása esetén saját fogyasztásra 1501-2000 Ft-ot költenek átlagosan a válaszadók, míg ajándékozásra a 2501-3000 Ft ársávba esett a legtöbb válasz. Válaszadóik jelentős része szerint más országokban is előállítható pálinka nevü termék. Ennél is beszédesebb, hogy a kitöltők majdnem egynegyede (23,10\%) szerint pálinkát gabonafélékből, sőt sokak szerint citrusfélékből (13,90\%) és burgonyából $(12,10 \%)$ is elő lehet állítani. A vásárlási szempont szerint leginkább a gyümölcs típusa számított, amelyből a pálinka készül, ezt követik az ismerösök ajánlásai, majd a termék ára. Míg a pálinkatörvény nagy hangsúlyt fektet a pálinkák eredetvédelmére, a fogyasztók vásárlási szempontjai között ez a tulajdonság csupán a negyedik helyet foglalja el. A válaszok alapján a fogyasztók leginkább az esküvőhöz, lakodalomhoz, házibulihoz kötötték a pálinka fogyasztását. A vizsgálatban a válaszadók jövedelmi helyzete nem befolyásolta szignifikánsan az egyes klaszterekbe való besorolást, ahogyan a válaszadók életkora és iskolai végzettsége sem. Kifejezetten meghatározó demográfiai paraméternek a csoportok elkülönítésében a válaszadók neme bizonyult.

Totth et al. 2018-as vizsgálata megerösíti az elmúlt évtizedek hazai italfogyasztási szokásvizsgálatok eredményeit, mely szerint a pálinka a fiataloknál kedvelt „buli előtti hangulatfokozó, gyorsító”, az idősebbeknél pedig egyfajta szakrálisnak tekinthető ital (Totth et al. 2018a). Vizsgálatukban kihangsúlyozták, hogy az otthon készített vagy bérfőzdében kifözetett párlat, a „házi pálinka” nimbusza töretlen. A házi pálinkával és a házi pálinkafőzéssel kapcsolatos asszociációk csaknem a megkérdezettek felénél (31 fó) voltak megfigyelhetők. A fogyasztói tájékozottság javulását támasztotta alá, hogy a megkérdezettek túlnyomó többsége (60 fö) tisztában volt azzal, hogy a pálinka elnevezés 2002 óta csak a 100\%-ban hazai gyümölcsböl készült párlatoknak jár, így figyelembe veszik a vásárlás során, hogy a csupán pálinkának tünő párlatok ne kerüljenek a kosarukba, amikor igazi pálinkára vágynak. A megkérdezettek pálinkafogyasztási alkalomként a baráti és családi összejöveteleket említették. A gyümölcsfajta-preferenciát tekintve a megkérdezett pálinkafogyasztók 
elsősorban a klasszikus ízeket részesítették előnyben, a legnépszerübb a szilva-, a barack-, és a körtepálinka volt. A megnevezettek sorából ezek a gyümölcsök kiemelkedtek, a harmadik helyezett körte az említések számát tekintve közel duplája volt a negyedik helyezett meggynek. A szilva- és a barackpálinkát jellemzően az első és második helyen, és hajszálra azonos arányban, míg a körtepálinkát többnyire a harmadik és a második helyen említették. A megkérdezettek többsége a házi pálinkát részesítette előnyben ízpreferencia nélkül: „nekem az íz teljesen mindegy, csak házi pálinka legyen”, „csakis a házi pálinka a pálinka, az íz nem számít, csak a minőség és a megbízhatóság". A szerzők megállapították, hogy a házi párlatok minőségileg rendkívül heterogén együttest képviselnek, valóban kiváló minőségü termékek, és az emberi fogyasztásra kevéssé alkalmas egyaránt található közöttük, de imázs szempontjából nagyon jól állnak. Ár tekintetében jelentősen többet szánnak a fogyasztók ezekre az italokra, mint az otthoni fogyasztásra és az ünnepi alkalmakra szánt pálinkák esetében. A vizsgálatban megkérdezettek az összes fogyasztási alkalmat figyelembe véve átlagosan 2500 és 6500 Ft között költöttek egy üveg pálinkára. Ünnepi alkalmakra 3000 és 6000 Ft között, míg a társasági eseményekre, családi, baráti összejövetelekre 2800 és 5500 Ft között költöttek. Saját fogyasztásra szántak a legkevesebbet, nevezetesen 2500 és 5000 Ft közötti összeget.

Totth és szerzötársai 2017-2018-ban 1207 fös empirikus kutatás keretében vizsgálták a pálinkafogyasztással kapcsolatos fogyasztói preferenciákat, a márkaismeretet, valamint a pálinkával kapcsolatos attitüdöket (Totth et al. 2018b). A megkérdezettek elsősorban családi, baráti összejövetelekre vásárolnak szeszes italt (80\%), saját fogyasztásra azonban csak $67 \%$. Az ajándék céljára történő vásárlások esetében a két leginkább preferált ital a whisky és a pálinka volt, a válaszolók közel harmada ezekkel az italokkal tesz eleget ajándékozási kötelezettségének, már amennyiben itallal kedveskedik. A whisky a legdrágább szeszes italok közé tartozik, vagyis itt volt a legnagyobb a maximumköltések átlaga (átlagosan $4060 \mathrm{Ft}$ és $8210 \mathrm{Ft}$ közötti értékben választanak ajándéknak), azt azonban érdemes megjegyezni, hogy a szeszesital-vásárlási alkalmak közül a legtöbbet az ajándéknak vásárolt szeszes italokra költöttek a válaszadók. A vizsgálatban részt vett válaszolók több mint negyede pálinkával ünnepel. A második helyen itt is a whisky szerepelt, a harmadik pedig a vodka volt.

A családi eseményekre, illetve a saját célra történő vásárlásoknál az átlagos maximumköltségeket összevetve a szerzők azt találták, hogy a brandy, a gin, a pálinka és a whisky esetében a megkérdezettek hajlamosabbak voltak saját magukat a család és a barátok elé helyezni, és magukra valamivel többet költeni. A férfiak gyakrabban vettek maguknak alkoholos italt saját fogyasztásra, és az átlagos maximum- és minimumköltésük összege is magasabb volt, mint a nőké. A legismertebb pálinkaízek: szilva-, törköly- és vegyes pálinka voltak, ami azért némileg meglepő, mert utóbbi két pálinka nem tartozik a kedveltek közé, tehát ebben az esetben az ismertség és a kedveltség nem jártak együtt. A legtöbben a szilva-, a kajszibarack- és az őszibarackízeket választották elsőként, a szilvapálinka esetében azonban a legmagasabb volt az elutasítók aránya, 31\%. A törköly- és a vegyes pálinkák elutasítottsága megközelítette az 50\%-ot, és mindössze 5-5\% volt azok aránya, akik ezeket választanák elsőként. A megkérdezettek döntő többségénél a pálinka nagyon szorosan összefügg a magyarsággal, a hagyományainkkal. Tízből kilenc válaszadó a 
pálinkát erős hungarikumként/ magyar italként jellemezte a vizsgálatban. Totth et al. (2018b) megállapítása szerint továbbra is él az emberekben a „házi pálinka” imázsa, mely szerint az igazi pálinka házi készítésü, csak gyümölcsből készül, bármely alkalomkor fogyasztható, és a fiatalok és az idősek is szeretik. A szerzők véleménye szerint a pálinka imázsa nem romlott, és továbbra is ez az az égetett szeszes ital, amelyet sokan vásárolnak, de a fiatalabb korosztályokban a legnagyobb versenytársnak számító whisky és vodka vásárlóinak aránya megelőzi a pálinkát vásárlókét.

\section{Következtetések és javaslatok}

A pálinka egy kizárólag Magyarországhoz köthető termék, amelyet értékes alapanyagból, esetenként ritka gyümölcsfajtákból állítanak elö, alapvető tulajdonságai révén is alkalmas, sőt méltó arra, hogy egy hatékony és sikeres marketingstratégia segítse népszerüsítését. A házi pálinka nimbusza az elmúlt időszakban töretlen, sőt a pálinkák iránti általános érdeklődés növekedése, valamint a házi fơzést és a bérfözetést segítő jogszabályváltozások kedvezően hatottak ezen termékek imázsának javulására. Azonban a házi fözés engedélyezése jelentős kárt okozott a kereskedelmi főzdéknek, akik úttörő szerepet játszottak a pálinka imázsának javításában, és a pálinkának, mint magas minőségü értékes magyar italnak az elfogadtatásában. Továbbá nem feledkezhetünk meg a feketekereskedelemről sem, ami a pálinka esetén fokozott veszélyt jelent. Az eddigi szakirodalmak feldolgozása azt mutatja, hogy továbbra is szükséges a pálinkafogyasztás alapos elemzése, a fogyasztói preferenciák és attitüdök részletes, a fogyasztói attitüd komponenseit is azonosító vizsgálata. Folytatni kell a pálinkával kapcsolatos tanító jellegü kommunikációt a különbségek - melyek a felületesen és nem szakszerüen pálinkának nevezett termékektől elválasztják őket hangsúlyozásával. Továbbá folytatni és erősíteni kell a pálinka pozicionálását, hogy minél szélesebb körben váljon ismertté: a pálinka az egyik legértékesebb alapanyagból elóállitott szeszes ital, mely kategóriájában értékét tekintve felveszi a versenyt a világszerte ismert és elismert magas minőségü termékekkel.

A dolgozatban említett változások, a kereskedelmi fózdék termelésének a visszaesése, a bérfözdék termelésének a bővülése, a „házi pálinkák” töretlen népszerüsége, valamint a fiatalabb korosztályok preferencia sorrendjében a pálinka visszaesése a versenyhelyzet erősödését eredményezte. Ez kihatott mind az iparágon belüli, mind pedig a szükebben vett (szeszesital) helyettesítő termékekkel folytatott versenyre. Ahhoz, hogy ebben a helyzetben úgy a pálinka, mint az egyes márkák/kereskedelmi fözdék helyt tudjanak állni, a marketingeszközök, tudatosabb és intenzívebb használata szükséges. Ehhez a fogyasztói attitüdök ismeretén kívül szükséges nem csak a pálinka és az egyes márkák imázsának, hanem az egyes imázsok komponenseinek a mélyebb, alaposabb ismerete. A házi pálinka sokszor érdemtelenül jó imázsa vélhetően részben affektív, részben konatív komponensekre vezethető vissza. Az imázs komponensek termék, illetve márkaszintú meghatározása segítheti elsősorban a kereskedelmi fözdéket - olyan marketingstratégia kidolgozásában amely mind a pálinka, mind pedig az adott márka versenyképességét növelheti. Kutatásainkat ezért ebben az irányban kívánjuk folytatni, a pálinkával kapcsolatos attitüdök, az egyes pálinka imázsok, és ezek komponenseinek a részletesebb, és mélyebb feltárására. 


\section{Kutatói támogatás}

Oravecz Titanilla (ÚNKP-19-3-III) valamint Mucha László (ÚNKP-19-3-I) publikációt megalapozó kutatása az Innovációs és Technológiai Minisztérium, Új Nemzeti Kiválósági Programja és a Budapesti Gazdasági Egyetem, Külkereskedelmi Karának Impact Project Programja keretében zajlott.
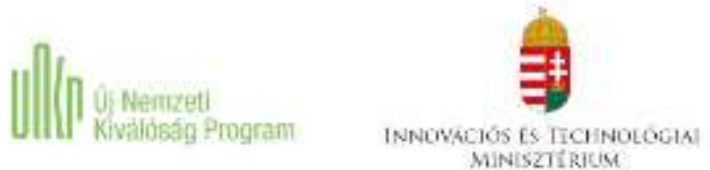

Az Innovációs és Technológiai Minisztérium ÚNKP-19-3-I kódszámú Új Nemzeti Kiválóság Programjának szakmai támogatásával készült.

\section{Felhasznált irodalom}

Agrárgazdasági Kutató Intézet, statisztikai jelentések, Élelmiszeripari kapacitásjelentés, 2016. év (revízió 2018. 5. hó), I, 1, 2017.

Agrárgazdasági Kutató Intézet, statisztikai jelentések, Élelmiszeripari kapacitásjelentés, 2017. év, II, 2, 2018.

Balázs, G. (2012): Nagy párlat- és pálinkakönyv. Inter Kft., Budapest, p. 147.

Béli, G. (2013): Pálinkajog és jövedéki szabályozás. Budapest Corvinus Egyetem, Budapest, p. 92.

Fodor, M. - Hlédik, E. - Totth, G. (2011): Fogyasztói vélemények és preferenciák a pálinka piacán. Élelmiszer, Táplálkozás és Marketing, 8, 1-2, 41-47.

GFK Hungária (2008): Piackutatás a pálinka népszerüsitö kampány megalapozására. Budapest.

Harcsa, I. M. - Nábrádi, A. - Tar, I. (2014): Hungarian spirits pálinka as a "Hungaricum" I. APSTRACT - Applied Studies in Agribusiness and Commerce, 8, 2-3, 133-141.

Hlédik, E. - Totth, G. - Fodor, M. (2011): A pálinkavásárlási döntést befolyásoló tényezők. Marketing \& Menedzsment, 45, 2, 16-22.

Jónás, J.(2006): Mesterpálinkák, pálinkamesterek. Korona Kiadó, Budapest.

NRC (2009): Aqua vitae - Made in Hungary. A fiatalok pálinkafogyasztási szokásai 2007., 2008., 2009. Budapest. NRC (2010): Pálinkafogyasztás 2009-ben. Pálinkafogyasztási szokások, jellemzők és folyamatok a 1849 éves magyar lakosság körében. 2010 01.15. Budapest.

OszKő Bt. - TNS (2003): Pálinkamarketingstratégia. Budapest.

Pálinka Nemzeti Tanács (2019):

https://www.palinkanemzetitanacs.hu/hu/aktualitasok/42 (letöltve: 2019.10.20.)

Panyik, G. - Béli, G. (2008): Gyümölcspálinka gyártása, jövedéki ismeretek. FVM Képzési és Szaktanácsadási Intézet, Budapest, p. 117. 
Panyik, G. (2006): Minőségi párlatkészités. Budapesti Corvinus Egyetem, Élelmiszertudományi Kar, Mezőgazda Kiadó, Budapest, p. 92.

Szegedyné, Fritz Á. - Szakos, D. - Bódi, B. - Kasza, GY. (2017): Pálinka, fogyasztói ismeretek, preferenciák, fogyasztói szokások, marketinglehetőségek. Gazdálkodás, 60, 2, 158-170.

Totth, G. - Fodor, M. - Hlédik, E. (2011a): A fogyasztói magatartás empirikus vizsgálata a pálinkafogyasztók körében. In Tudományos Évkönyv 2010: Merre tovább? Gazdaság és társadalom, realitás és esély. Budapesti Gazdasági Föiskola, p. 48-61.

Totth, G. - Hlédik, E. - Fodor, M. (2011b): Pálinkával kapcsolatos fogyasztói percepciók és preferenciák elemzése kvalitatív kutatás eredményeinek a tükrében. Marketing \& Menedzsment, 45, 2, 11-15.

Totth, G. - Kovács, I. - Mezőné, O. T. - Zarándné, V. K. (2017): A fiatalok pálinkafogyasztási szokásai. In Bányai, E.- Lányi, B.- Törőcsik, M. (szerk.): Tükrözödés, társtudományok, trendek, fogyasztás: Egyesület a Marketing Oktatásért és kutatásért (EMOK) XXIII. országos konferencia: Tanulmánykötet, 230-238.

Totth, G. - Mezőné, O. T. - Zarándné, V. K. (2018a): A pálinka fogyasztási és vásárlási szokásainak kvalitatív vizsgálata. Prosperitas, 2018, 2, 100-115.

Totth, G. - Mezőné, O. T. - Zarándné, V. K. (2018b): A pálinkafogyasztás és a fogyasztói szokások változása. Prosperitas, 2018, 2, 87-98.

Totth, G. (2009): Stratégiai kihívások a megváltozott gazdasági környezetben a minőségi pálinka hazai forgalmazásában. In Losoncz, M. - Solt, K. - Szigeti, C. (szerk.): Kautz Gyula emlékkötet: Halálának 100. és születésének 180. évfordulója alkalmából. Széchenyi István Egyetem, Győr, 233-242.

Totth, G. - Zarándné, V. K. - Hlédik E. (2016): A pálinkafogyasztási szokások változása. Egyesület a marketing oktatásért és kutatásért XXII. Országos konferencia, Hitelesség és Értékorientáció a Marketingben 2016. augusztus 30-31. 